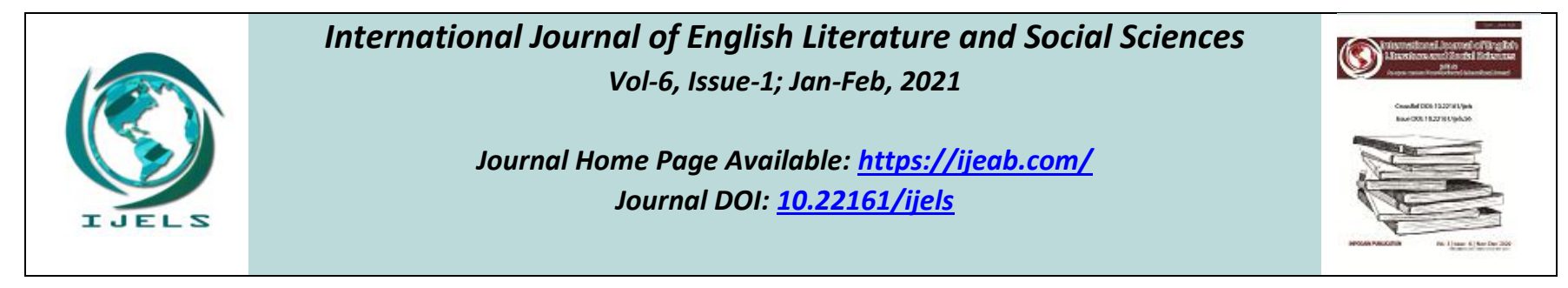

\title{
Sudha Murthy: An Eminent Contributor to Literature
}

\author{
Nishtha Vaswani
}

$3^{\text {rd }}$ year student, B.A. LLB, Symbiosis Law School, Hyderabad, India

Received: 07 Nov 2020; Received in revised form: 08 Jan 2021; Accepted: 15 Jan 2021; Available online: 21 Jan 2021

(C)2021 The Author(s). Published by Infogain Publication. This is an open access article under the CC BY license

(https://creativecommons.org/licenses/by/4.0/).

\begin{abstract}
They appear in motion pictures that ladies who carry dark attire, wacky haircut, tattoos and pull off insane tricks are boss, yet do they realize that a lady wearing a straightforward cotton dhoti can be an all-out boss, in the real world where we normal people live? Mother Teresa was one of those ladies. Furthermore, Padma Shri Sudha Murthy is one more name that goes on that rundown. Sudha Murthy is a person who has marked her presence by doing the extreme works in that era or that period wherein women, in general, were neither given any support nor were appreciated to work and study. Sudha has devoted her life so much to the society that it can be reflected in her written work as well as practical life.
\end{abstract}

There are number of write-ups of Sudha in which the reality of society is highlighted which she has faced herself while she travelled the nation around and also some foreign trips which she had done. Her work is emotional, truthful and so real, that the reader is touched and can feel the aura of the story around. Every author has a story behind writing a book which Sudha also has, but the only difference is, her behind the story is so realistic that creates an interest in readers to read the book. The amazing thing about her love for literature is that she does not only stick to one type of work, but there is also so much variety one can infer from her work and that is very exciting.

Sudha stands as an eminent and worthy example for everyone that money does make you everything, it is your work and behaviour that has to follow it which should be humble and full of dignity.

Keywords-Sudha Murthy, Literature, Indian fiction.

\section{INTRODUCTION}

Sudha Murthy was born in a Brahmin family to Dr R. H. Kulkarni and Vimala Kulkarni on 19 August 1950 in Shiggaon in Karnataka. She was raised by her folks and maternal grandparents. These youth encounters structure the verifiable reason for her first outstanding work entitled "How I Taught my Grandmother to Read", wise and Otherwise and other Stories. She finished B.E. in Electrical and Electronics Engineering from the B.V.B. School of Engineering and Technology (presently known as KLE Technological University), she ranked first in her batch and received a gold medal from then Chief Minister of Karnataka. She finished M.E. in Computer Science from the Indian Institute of Science, standing first in her group and getting a gold award from the Indian Institute of Engineers.(Negi, 2017) She started her profession in software engineering and designing and currently is the director of the Infosys Foundation and an individual from general human services activities of the Gates Foundation. She has established a few orphanages, took part in country improvement endeavours, bolstered the development to furnish all Karnataka government schools with computers and libraries and built up 'The Murthy Classical Library of India' at Harvard University. Sudha Murthy started a strong move to present computers and libraries in all schools in Karnataka and also taught software engineering. She got "Best Teacher Award" from Rotary Club at Bangalore in 1995. "Sudha Murthy is mostly known for her social work 
and her commitment to writing in Kannada and English. Dollar Sose (English: Dollar Daughter-in-Law), a novel initially wrote by her in Kannada and later converted into English as Dollar Bahu, was made a serial and broadcasted by Zee TV in 2001."(Govind, 2019)Sudha Murthy turned into the first female to be enlisted at India's biggest vehicle producer TATA Engineering and Locomotive Company (TELCO). She joined the organization as a Development Engineer in Pune and later worked in Mumbai and Jamshedpur also. She wrote a letter to the organization's Chairman mentioning about discrimination which was there at TELCO because they recruited only men. Accordingly, she has conceded an extraordinary meeting and contracted right away. She joined Walchand Group of Industries at Pune as Senior Systems Analyst later on. She began Infosys Foundation back in 1996 and till date has been the Trustee of Infosys Foundation and a Visiting Professor at the PG Center of Bangalore University. She even was a teacher at Christ University. She has given numerous books, of which some are travelogues, technical books, novels and educative books. "Also, the two foundations of higher learning, the H.R. KadimDiwan Building lodging the Computer Science and Engineering (CSE) office at IIT Kanpur and the Narayan Rao Melgiri Memorial National Law Library at NLSIU, were both invested and introduced by the Infosys Foundation."(Krishnana, 2015)

Her works are included as course material in schools which show that she has written educational works and has taught the real meaning of life to children and youth both. Her stories tell that very naturally and emotionally. In one of her stories, she has described an old aged grandmother so beautifully which is a chapter in one of the English subjects in school. Sudha Murthy makes literature look so beautiful and gives life to the characters which she is mentioning in her book.

This paper intends to bring out the works which are done by Sudha Murthy and to analyze few of them and reflect her contribution to the field of literature and how she stands as a role model for many human beings.

\section{RESEARCH METHODOLOGY}

The works of Sudha Murthy have been analyzed by viewing her updates on newspapers, on social media and the videos of her interviews. Her work is extremely appreciable and is worthy of being read and to get some lesson from. This study is a theoretical study of some of her famous works and what are thoughts of Sudha Murthy behind the book which she has written. This paper will portray her efficient work as a writer and as a social worker. She is a big inspiration and her work must be looked upon as an example for bringing out the reality of society. She has written some mythological stories also which show how women in past have fought to overcome the cruelty in society.

\section{THEME IN SUDHA MURTHY'S WRITINGS}

Word theme refers to a core notion around which the novel's action is woven. It is the subject of a book. A novelist writes for a reason. He or she intends to offer some message, attack some undesirable behaviours in person or society, spread some ethics among the readers, present a social problem, narrate historically significant events with a new perspective etc. A novelist, in short, writes with certain intentions. "He communicates not in vacuum. In every novel there is usually one dominant theme and several less dominant ones to support it. The supporting themes can emerge to illustrate the basic theme by parallel themes or conflicting themes. Indian fiction writers in English have written on the topics of castes, classes, social inequality, oppression, isolation, discrimination, unemployment, rural and urban gap etc. A novelist can simultaneously discuss one or more of the above subjects. In reality the grandeur of a novel depends on the efficient handling of different themes in a single work."(06_chapter1.pdf)

Sudha Murthy illustrates regarding various kinds of issues in her write-ups and her writings are not limited to the issues of women alone. Her writing demonstrates a marked change to feminine writing in the overall viewpoint. "It is a common practice in feminine writing to blame men for women's sufferings, as if men and women were born rivals and marriage was a license to carry out a men's women's oppression agenda. Sudha Murthy is probably the first Indian writer in English to rationalize the problem by blaming one woman and the man in the family for the misfortunes of another woman. All four of her novels display the complicated relationships between two women in one family."(Negi, 2017)Another theme Sudha Murthy explores is the diminishing impact of rising capitalism on close human relationships in Indian society. Liberalization in the Indian economic system provided the Indians with hundreds of opportunities to accumulate capital. "Young boys and girls were given a chance to travel to countries of the first world and easily access modern facilities. It altered their social and financial standing, on the one side. On the other side, it generated friction in typically close relationships within the family. Sudha Murthy dealt artistically with collapsing household ties in all her 
works."(Govind, 2019)Her works include several minor themes. The Indians are superstitious, in general. They believe in the caste system, particularly in the fixation of marriages. Horoscopes, propitious dark times, rituals, practices, conventions, religious beliefs are playing their part in Indian's everyday lives. Sudha Murthy immaculately brings out inconsistencies in the lives of Indians in all her works.(06_chapter1.pdf)

\section{CHARACTERIZATIONIN SUDHA MURTHY'S WRITINGS}

Character in a work of art is usually a being with human or divine attributes. It is an individual able to perform actions. It is built through the interaction between the character readers and the textual representation. It is defined by Margolin as "Character refers to any person, individual or group, normally human or supernatural, inserted in a narrative fiction work. Characters therefore reside within the worlds of fiction and play a part in one or more of the states of affairs or incidents spoken about in the plot, no matter how small. Character can be described succinctly as a participant in the world of stories." Characterization is a process where a writer shapes anindividual into a personality, a simple name into an identity. The capacity of the writer to make this transition defines a writer's skill, or otherwise. "Writer uses different forms, such as descriptions, discussions, dialogues, interior monologues to give it a touch of verisimilitude."(Krishnana, 2015)Characters were generally classified into heroes, villains and minor characters as per their appearances throughout the novel, traditionally. They were often called major and minor characters depending on the role they were performing in the novel. In recent times, conventional division of characters into flat and round characters is finished. Including words such as protagonist and main hero, characters indicate a change in our hero paradigm, which was supposed to be noble, courageous and complex in the past. "Today we have characters from subaltern section of the society. Bakha in Untoucahble, Munoo in Coolie, Balaram in The White Tiger, Velutha in The God of Small Things, Rukhamani in Nectar in a Sieve, and likes have occupied central stage in the novels today."(06_chapter1.pdf)With recent developments in the field of psychology and anthropology, characterisation art has gained new aspects. The character's minds contain descriptions of disruptions along with the descriptions of their physical appearances. "Readers are supposed to read their minds to discern the truth behind the actions of characters. Characterization is rich and realistic through the efforts of the writer to place his characters with new characters in various circumstances. Characterization depends on the abilities of the writer with which he creates his characters in relation to one another."(Krishnana, 2015)One of Sudha Murthy's character's striking features is that they come from middle-class backgrounds. They are from either the world of education or the service sector. Sudha Murthy binds them simultaneously with the conventional Indian society and with the ultramodern society today. "The majority of young characters are engaged in their growth professionally and personally. The old characters are drawn to wealth but in other ways are unable to improve themselves. In the modern world of technology results in conflict between the old and the new, ancient practices, customs and conventions."(S. PARVATHI, 2016)

The comparison of female characters of Sudha Murthy with the female characters of other Indian female novelists, one finds that the women of Murthy have a positive approach to life. They value hard work. Their take on life is highly enthusiastic. "Rukhmini's Kamala Markandaya resigns to fate. She is a destitute being in the grip of cruel fate. Tanner evacuates her from her old home. Her kids are ditching her. Society is treating her poorly. She faces all of that passively, without grumbling. Strong powers rule her outside. Sudha Murthy's women plan their own fate. Mahashweta and Mridula do not go down to circumstances. The situations are not down to Mahashweta and Mridula.They rather work to bring about a change in external situation."(Govind, 2019)

"The characterisation of Sudha Murthy lacks imagination. She struggles to dive deep into her character's psychological crises. Young boys and girls get married and start a relationship. The two do not have intimate outings. This is very odd. Without wandering and dating it is impossible to expect modern boys and girls with high academic credentials and knowledge to get into marital relations."'S. PARVATHI, 2016)Despite these shortcomings, her characterization art is clear and direct in keeping with the storytelling tradition in India. As a result, novels of Sudha Murthy and short stories cater to today's Indian reader's section only. She stands out as an excellent narrator because of her devotion to Indian culture and not because of copying the westerners. This goes on to prove that India has evolved but that the Indians have not.(Govind, 2019)

\section{NARRATIVE TECHNIQUEIN SUDHA MURTHY'S WRITINGS}

The way the story and the events are depicted is called the technique of narration. A writer by use of 'first person narration' tells his story. In this, the character narrates 
the events and incidents of his life himself. "First person storytelling typically uses the method of recollection to recall one's past. Sometimes writer creates a narrator who unfolds the action through its eye. The writer makes use of this strategy to keep his distance from the characters. The third form of narrative strategy is the author himself takes the reigns of the work's action into his hands. Most authors adopt this technique."(06_chapter1.pdf) In the $20^{\text {th }}$ century, a technique called 'Streams Of Consciousness' evolved. M. H. Abrams describes Stream of Consciousness as "Stream of Consciousness is the name for a special mode of narration that undertakes to reproduce, without a narrator's intervention the full spectrum and the continuous flow of a character's mental process, in which sense perceptions mingle with conscious and half-conscious thoughts, memories, expectations, feelings and random associations." One of the remarkable highlights of good composing is its capability to constrain readers to the story. It isn't the author alone who composes. "The readers who are the audience are equivalent stake holders in the arrangement of the content. Allegorical passing of a creator implies the introduction of readers in the imaginative demonstration. Genuine creator makes co-creators who guide and screen his or her composing. This procedure of aggregate composing is incredibly important in the energy about a narrator."(Negi, 2017)Sudha Murthy lamentably neglects to make co-writers and co-readers. She presents, clarifies and deciphers her characters leaving almost no place for readers to do anything. This may suit customary Indian technique for narrating. Although it makes her works one-sided, she stays a focal point of fascination for the new readers of India. This must be thought about the incredible support of Indian writing. "Sudha Murthy sets her books by weaving the strings of customs and advancement in all her works. Indians of the old age even today gloat of their social legacy. Numerous Indians are pleased with it. Sudha Murthy sets the activity of her books in the towns what's more, provincial inclinations that exist in huge urban communities. Juxtaposition of country existence with cosmopolitan life of the urban areas makes her work illustrative of in general Indian life. It likewise causes her to draw out the showdown between two ages."(D. Nivetha, 2008) "In spite of the fact that Maharastrian by birth, she has settled her business realm and humanitarian work essentially in Karnataka. Normally she is very much familiar with the individuals and their ways of life around there. Her characters have Kannada names like Akka, Appa, Avva and so forth. This doesn't be that as it may imply that her books are territorial in extension and bid. We discover individuals with such qualities somewhere else in India. Her expertise to grow the canvas of her books is essential."(Govind, 2019)

\section{CONCLUSION}

Sudha Murthy has proved that the simple use of words can also express ideas and views efficiently. One does not always have to use sophisticated language or phrases to show the importance or talent of the literature. Sudha Murthy's write-ups are so easily accessible to in terms of understanding that it becomes a point of attraction for any reader. The connectivity between the audience and the story generates quite easily. This works as a plus factor for any writer or narrator. These skills of Sudha Murthy are highly remarkable and show her dedication and efficiency in storytelling and expressing her ideas.

\section{REFERENCES}

[1] 06_chapter1.pdf. (n.d.). Retrieved from https://shodhganga.inflibnet.ac.in/bitstream/10603/192026/8/ 06_chapter1.pdf

[2] D.Nivetha. (2008). Sudhā Mūrti - 2008 - Gently falls the bakula.pdf. Retrieved from https://www.worldwidejournals.com/paripex/recent_issues_p df/2018/March/March_2018_1520433975_112.pdf

[3] Govind, R. (2019, 11 27). Sudha Murthy's new book profiles strong, brave women from mythology. Retrieved from https://www.thehindu.com/books/books-authors/sudhamurthy/article30096474.ece

[4] Krishnana, V. (2015, 08 19). This Story Of Infosys Founder Narayan Murthy's Wife 'Sudha Murthy' Will Make You Salute Her. Retrieved from https://www.comedyflavors.com/infosys-founder-narayanmurthys-wife-sudha-murthy/

[5] Negi, D. (2017, 08 19). Brilliant, Brave \& Badass, Sudha Murthy Is The Kind Of Role Model We Women Need Today. Retrieved from https://www.scoopwhoop.com/sudha-murthyand-her-inspiring-journey/

[6] S. PARVATHI, D. S. (2016). 'QUEST FOR SELF' IN THE SELECT NOVELS OF SUDHA MURTHY. INTERNATIONAL JOURNAL OF ENGLISH LANGUAGE, LITERATURE. 